\title{
Exploration of Work Attributes in the Synergy of Institutions to Improving the Quid Pro Quo of Tourism
}

\author{
BAMBANG SUPRIADI \\ University of Merdeka Malang, Jl.Terusan Raya Dieng 64 Malang, Indonesia \\ correspondence author: bambang@unmer.ac.id
}

\begin{abstract}
Importance Performance Analysis (IPA) provides a useful facility to test the institutional synergy concept among tourism stakeholders. This research has a purpose to explore the perception of tourism stakeholders concerning the attributes in the value of importance and performance in tourism institutions to increase quid pro quo for the community. This study was conducted in sub-districts that have potential migrant or Indonesian Migrant Worker populations in Malang District. Samples of this research are tourism stakeholders who manage tourist attraction in productive migrant villages. They are tourism activist groups as tourism actors in the community, village government work units, and Perusahaan Daerah Jasa Yasa (Jasa Yasa Regional Company) as the manager of the tourism. The analytical tool used to measure the level of performance and importance in the synergy attributes is the Importance Performance Analysis (IPA). The results of this study show the attributes of synergy between tourism stakeholder institutions have the following distribution: Environmental Changes attribute falls in Quadrant I; attributes of Continuous Coordination, Simultaneous Responsibility, Effective Communication, \& Simultaneous Supervision fall in Quadrant II; Simultaneous Policy and Direct Relationship attributes fall in Quadrant III; and Obvious Purpose attributes falls in Quadrant IV.
\end{abstract}

Keywords: Performance, Synergy, Tourism,

\section{Introduction}

The problem of migrant workers arises because of limited domestic employment opportunities, the occurrence of wage disparities that are far different from wages abroad, and the less-productive income from abroad which rather be used for consumption (Ministry of Manpower and Transmigration / Kemenakertrans, 2017). The District of Malang is the biggest contributor to international migration in East Java Province. This is due to not only conditions of low income, but also the limited available jobs in the village that causing many residents to migrate (Prayitno, 2013).

According to the Ministry of Manpower and Transmigration (2017), Productive Migrant Village is a village where most people work abroad, have a knowledge of the placement and protection system of workers both at home and abroad, and are able to build a productive independent business through the role of synergy from the stakeholders of both the village governments and other stakeholders.

The number of Indonesian migrant workers in Malang District for countries in Asia (Hong Kong, Singapore, Malaysia and Taiwan) overall increased by $21.8 \%$ in 2015 $(1947)$ and $2016(2,490)$ (Central Statistics Agency (BPS), 2017). The problem of migrant workers, if the solution is not immediately and wisely sought, will have an impact on family psychology, the emergence of trafficking in person, the high number of illegal migrants, and the increasing number of cases of migrant workers abroad. More detailed data is presented in Table 1.

Currently, it is still difficult to conduct direct synergy activities among tourism 
stakeholders to realize effective cooperation through direct or personal relationships since this direct synergy is an urgent attribute. However, the performance of institutional synergy is still not optimum. These problems can occur due to environmental influences and changes, both internal and external. Therefore, the purpose of this study is to explore the synergy attributes of the stakeholders in the performance of productive migrant village tourism businesses to increase quid pro quo (the awarding of Service Award) for the welfare of the people from tourism sector. This applied research is crucial since the poverty rate in Malang District is still quite high which is above $11 \%$ (BPS, 2017).

TTable 1

Growth of Migrant Worker in District of Malang

\begin{tabular}{cccccc}
\hline & HONGKONG & SINGAPORE & MALAYSIA & TAIWAN & TOTAL \\
\hline $\mathbf{2 0 1 5}$ & 774 & 80 & 54 & 1.039 & 1.947 \\
$\mathbf{2 0 1 6}$ & 996 & 246 & 30 & 1.218 & 2.490 \\
\hline $\begin{array}{c}\text { Growth } \\
\text { (\%) }\end{array}$ & 29 & 208 & -44 & 17 & 28 \\
\hline $\begin{array}{l}\text { Source: Central Statistics Agency, District of Malang (2017), Modified. } \\
\end{array}$
\end{tabular}

Brouder and Rikard (2013), state that the synergy activities of economic geography and tourism studies can provide a quid pro quo value with long-term prospects for the tourism sector. When there are joint activities, tourism institutions can unite in a multidisciplinary spirit. The spirit of tourism institutional synergy, if it is manifested perfectly, can provide works in the village for migrant communities.

Recognizing the problems of migrant workers mentioned above, then a solution is needed to overcome those problems through creating synergy between stakeholders to achieve effective cooperation. One form is to synergize through direct relationships and personal relationships. A continuous process can be started from the planning stage. Dynamism and adjustments need to be changed continuously, taking into account changes in the internal and external environment by reducing conflict in order to help to unite the goals. Effective communication can act as an intermediary. Effective supervision will ensure the smooth synergy of activities at the planning level.

In order to overcome the above problems, this study uses approach from stakeholder theory approach (Weiss, 1995), a theory that explains factors influence the integration in running a long-term and sustainable tourism business, such as the results of a study concerning tourism business conducted by Dibra (2015). The implication of the results of this study is to improve the economic development of local communities, institutions, and tourism actors in order to be able to run institutional synergies in the tourism sector so that it can help promote the potential of regional tourism.

Apart from a large number of research contributions in the field of tourism, the construction of interdisciplinary tourism performance evaluation has not yet been fully explored. Thus, there is a need to bridge this gap and draw insights from research on attributes in the social-tourism sector to understand organizational performance. It is expected that the practical contribution from the research on performance attributes can be relevant for practitioners of tourism business management and academics in aligning the performance attributes of tourism institutions. Thus, in order to realize the contribution of practitioners managing this tourism business, the activities of Productive Migrant Villages can be focused on implementing mutually supportive and sustainable programs, including providing Information and Services for Migrants or Migrant Workers, developing Productive Enterprises which can help small enterprises run and owned by Indonesian Migrant Workers, and also facilitating the establishment of a Childcare and Growth Care Community (Kemenakertrans, 2017) and (Latifah, 2014).

Productive Migrant Villages implement their main activities integratedly, mutually supportive, and sustainably. Those main activities are as follows: providing immigration information or services for migrant workers, developing productive businesses to support migrant workers and their families (Afrindo, 2014), promoting the establishment of a childcare and guidance community, training and developing creativity through the "PMV Learning House" (Giambi et. al, 2018), as well as promoting the formation and development of cooperatives/financial institutions.

This study of institutional synergy adopts the theory of organizational innovation (Roger, 1995), that is an innovation model in organizations based on the diffusion theory of main group innovations. Factors affecting innovation adaptation are the most appropriate conceptual models for sustainable tourism businesses. Roger's model factors can adapt to the current tourism industry 
and are used by countries that have tourism destinations.

Furthermore, the theory of organizational innovation was degraded to be more operational and becoming a middle theory called stakeholder theory (Weiss, 1995). It has advantages in explaining factors influence the integration in running a tourism business. This is what Dibra (2015) did when discussing the Factors that Influence Integration in Tourism Business. In the perspective of tourism business, Dibra used a theoretical model of stakeholder theory, bearing in mind that this theory has advantages in explaining the factors that influence the integration of tourism business. Thus, this institutional tourism synergy research can be said as adopting stakeholder theory.

Stakeholder collaboration of innovative theories is also used by Beik (2018) regarding policy innovations from stakeholder institutions. Stakeholders are defined as individuals, groups, or organizations that can make or are affected by organizational claims and concerns, resources, or outcomes (outputs). Another definition of stakeholders in Pitana et al. (2018) is the tourism actors who are supported by three main pillars, namely regulators or facilitators, supporters or owners of tourism capital, and the community. These three pillars can be said to be elements of government (Sedarmayanti, 2018). Basically, the elements of governance (governance stakeholders) can be divided into three categories, namely: (1) Government, which is in the form of state activity / Ministry Of Tourism; (2) The private sector, such as manufacturing, trade, banking and cooperatives, including information sector activities/industry; and (3) Society or community groups, namely tourism activist groups, both in the context of individuals and community groups who interact socially, politically, and economically in tourism (professional organization and entrepreneur). Connection among the tourism sectors can be seen in Figure 1.

The concept of synergy has been referred to in the innovation management literature theory by Ansoff (1965). In Corporate Strategy, he described the basis of economic synergy - how different businesses can add from their sum. According to Ansoff, the synergy equation is based on the benefits of economies of scale, which also includes the benefits of "managerial synergy". According to
Itami and Roehl (1987), the synergy results from the process of using better resources, including physical assets such as industrial facilities, and invisible assets such as brands, customer knowledge, technological expertise, and corporate culture.

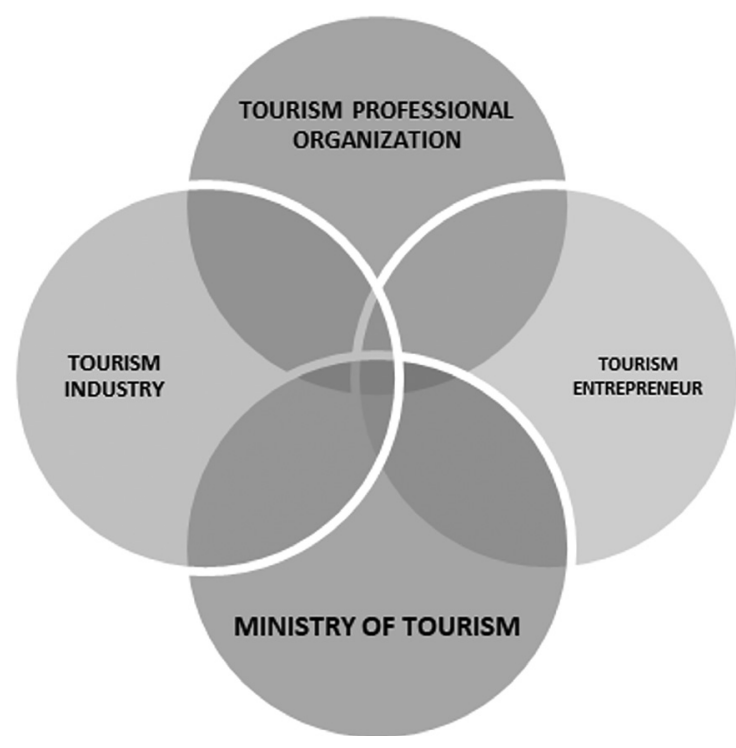

Figure 1. Connection among Tourism Actors

Synergy is also called synergism or synergy. In (Walton et al. 1999), synergy is the result of a collaborative effort or 'cooperative effort', therefore, the core of the process needed to produce quality synergy is cooperation and cooperation requires effective synergy in its implementation.

Silalahi et al (2018) mentioned that synergy is the integration of individual activities and units into a joint effort, which is working towards a common goal. Moekijat (1994) mentions 9 requirements to implement effective synergy, namely: (1) direct relationship; (2) initial opportunity; (3) continuity, that is the process of continuous coordination; (4) dynamism, namely adjustment to environmental changes, both internal and external; (5) clear goals for obtaining effective coordination; (6) simple organizational structure; (7) clear formulation of authority and responsibilities; (8) effective communication; and (9) effective supervision leadership.

The growth of the creative tourism industry has built a road map for the development of priority industry clusters (Ministry of Trade/ Kemendag, 2012), which includes: (1) Group 1, agriculture industry, fisheries processing industry, and 
dairy processing industry; (2) Group 2, transportation equipment industry, shipping industry, aerospace industry, and railroad industry; (3) Group 3, support for creative industry, craft and arts industry; (4) Group 4, special small and medium industries, including stone and jewelry industry, ceramics, pottery and decorative industries, and the snack industry.

In general, tourism synergies and management systems generally consist of the following parts: management activities, operational activities, security activities, and maintenance activities. Each discipline controls its own discipline, related objects and travel attractions.

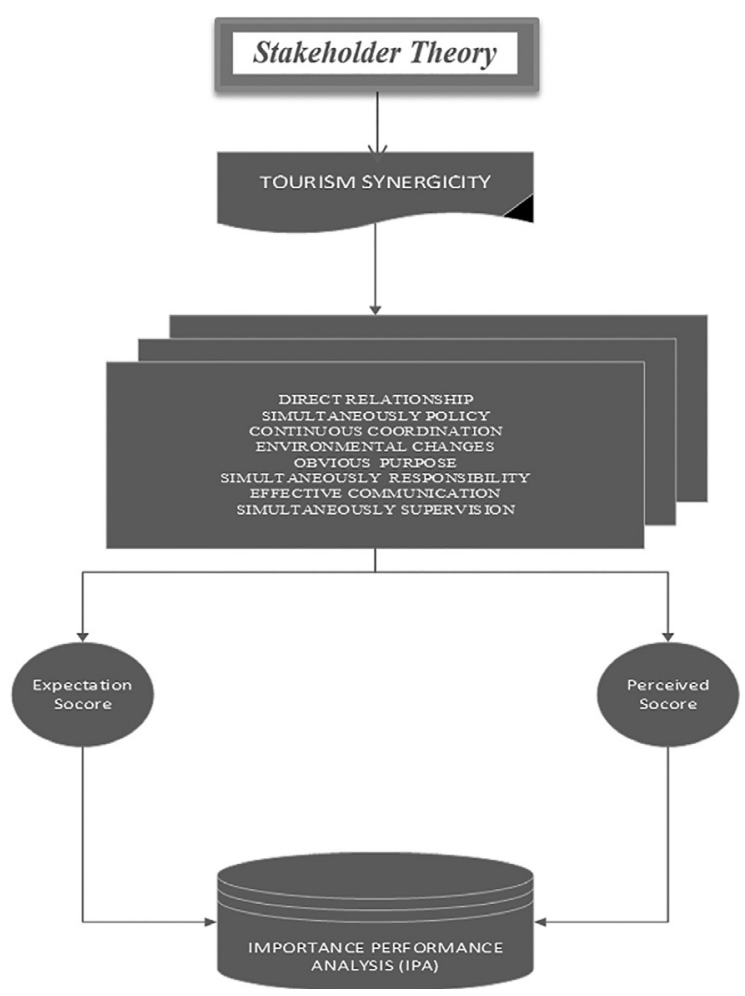

Figure 2 Theoretical Framework

The theoretical conceptual framework in Tourism Institution Synergy refers to the opinion of Dibra (2015), where factors that influence integration in tourism business employ the stakeholder theory model considering it has advantages in explaining those factors. Next is synergy tourism to find expected and perceived scores based on Importance Performance Analysis (IPA). The theoretical framework of the concept in detail can be seen in Figure 2 .

Previous research on the relationship between migrant villages and tourism that can be used as a reference for the Decentralized Management of Tourism Enterprises is as follows: The Synergies of the Italian Wine and Tourism Sectors (Santeramo, Seccia, and Nardone, 2017). It concluded that the area of origin of the tourists is a determining factor in the selection of destinations. There is a role of customer loyalty, as well as the relevance of political implications where institutions and political actors can exploit the synergy between tourism and beverage industry by promoting beverage excellence. The results of research by Brouder and Rikard (2013) in the tourism sector found that the synergy of the tourism sector in Italy in terms of geography of the economy can provide a quid pro quo (compensation) in the form of long-term prospects if tourism studies can unite in a multidisciplinary spirit. Initial efforts have shown that between them there are empirical and theoretical synergies (Brouder \& Rikarad, 2013), and there is room for further development that will produce results in the progress of tourism.

Migrant Relationships and Tourism Employment (Janta et al, 2011) examines variables on migrants and tourism. The findings of the study are about migrant work experience and tourism employment opportunities that affect migrant workers in their home communities. Meanwhile, Migrant and Foreign Skills and Their Relevance to the Tourism Industry (Aitken, 2010) examined variables on the relevance of foreign skills and the success of the tourism business in the tourism industry in New Zealand. The research findings state that the need for foreign skills for migrants will have implications for the tourism business (human resource policies, educational institutions, and immigration policies). The last one is a study entitled Migrant Workers: Challenges and Opportunities in Addressing Tourism Labor Shortages (Joppe, 2012) that examines variables on the challenges and opportunities of Migrant workers. The findings are that to date, most of OECD (Organization for Economic Co-operations and Development) member states have ignored the challenges and opportunities of the tourism industry related to migrant workers.

Government synergy in the development of tourism in migrant villages requires institutional roles, such as the Regional Government Work Unit in tourism development, including the roles of the Tourism Office, the Directorate of Highways, 
the Regional Revenue Management Agency, Industry Agency, Micro \& Medium Enterprises, and the Office of Education and Culture. Government synergy in the development of migrant village tourism in Malang District leads to the planning and development of tourist destinations, human and institutional resources, access $\&$ infrastructure, promotion \& marketing, creative economy, and security guarantees. For a more detailed diagram, see in Figure 3.

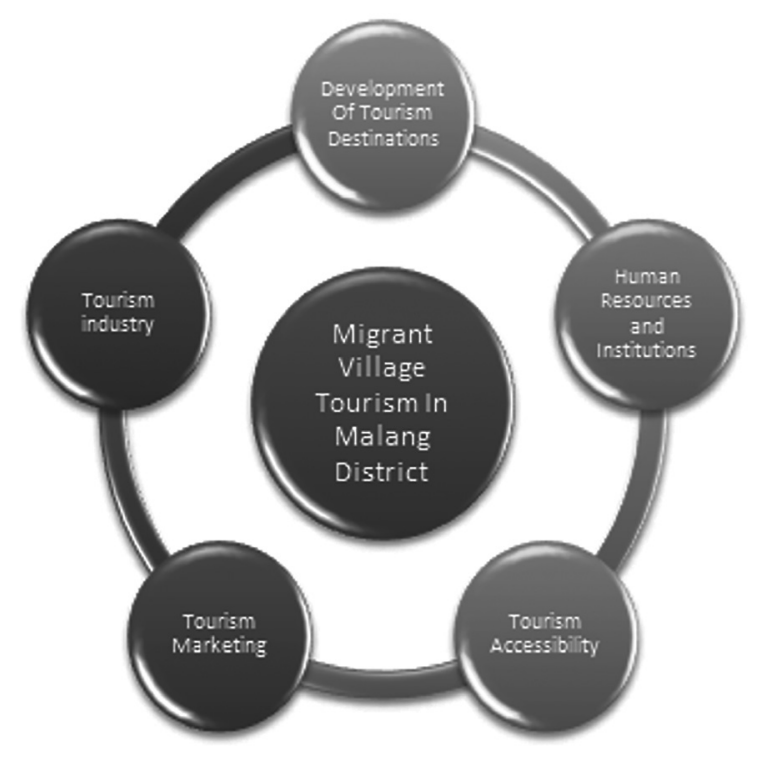

Figure 3. Synergy in the Development of Tourism

\section{Research Methodology}

The research locations were in 6 (six) sub-districts in the southeastern part (32-70 Km) of District Malang and focused on sub-districts and villages that have the potential of migrant or Indonesian Migrant Worker population who work abroad. The number of samples was 8 respondents from 6 districts. Samples were taken based on recommendations from the Malang Regency Manpower Office which produced the following: (1) Arjowilangung Village in Subdistrict Kalipare (38 km); (2) Sumbermanjing Village (70 km); (3) Brongkal Village in Subdistrict Pagelaran/32 km; (4) Donomulyo Village in Sub-district Donomulyo; (5) Gedangan Village in Sub-district Gedangan $(65 \mathrm{~km})$; and (6) Sub-district Bantur (50km).

The research has been through the initial stages (preliminary survey) to find out social gaps (job opportunities, illegal migrants, and migrant productivity) and discover the existing conditions of stakeholder performance in conducting cooperative activities in productive migrant villages.

The concept of variables and statement items about the synergy between stakeholders is considered to have a form of cooperation. Achieving goals through cooperation requires a synergy. Effective synergy can be carried out through eight conditions (Wahyudi, et al., 2018): Environmental Changes, Simultaneous Policy, Continuous Coordination, Simultaneous Responsibility, Obvious Purpose, Direct Relationship, Effective Communication, and Simultaneous Supervision. The statement items in accordance with the variables can be seen in Table 2.

Table 2

Variables of Synergy in Tourism Stakeholders

\begin{tabular}{ll}
\hline \multicolumn{1}{c}{ Variables } & \multicolumn{1}{c}{ Statement Items } \\
\hline Environmental Changes & $\begin{array}{l}\text { Tourism stakeholders' perception in managing } \\
\text { (X1) }\end{array}$ \\
& $\begin{array}{l}\text { migrant tourism village states that it is very } \\
\text { important and having performance in term of } \\
\text { continuous coordination in countering } \\
\text { environmental changes }\end{array}$ \\
Simultaneously Policy (X2) & $\begin{array}{l}\text { Tourism stakeholders' perception in managing } \\
\text { migrant tourism village states that it is very }\end{array}$ \\
& $\begin{array}{l}\text { important and having performance in term of } \\
\text { drafting specific regulations. }\end{array}$ \\
Continuous Coordination & $\begin{array}{l}\text { Tourism stakeholders' perception in managing } \\
\text { (X3) }\end{array}$ \\
migrant tourism village states that it is very \\
important and having performance in term of \\
conducting continuous or periodical \\
coordination.
\end{tabular}

The sample of this study is tourism stakeholders who play a role in managing tourist attraction in productive migrant villages. They are tourism activist groups as tourism actors in the community, village and sub-district government work units that intersect with tourism activities, and Perusahaan Daerah Jasa Yasa as the manager of the tourism. 
The analytical tools employed in this study is Importance Performance Analysis (IPA) through IBM SPSS Statistics 2.0 program, which is used in the research process of (Deepa, 2019) concerning Guide employer branding strategies in the ITBPM industry, and (Dabestani, et al, 2016) concerning Service quality dimensions for the customer groups segmented by DEA: The case of four star hotels.

The calculation results of the formulas were submitted into a cartesius diagram whereby the indicators deemed as achievement were found and need to be maintained. In addition, it also found indicators with low quality that required recommendations for priority improvement. The next step was performing strategic positioning of IPA.

Deepa (2019) explained Strategy of Importance Performance Analysis (IPA) has positions for data placement to specify sections. There is Quadrant I, the "Concentrate Here" that has high score from the aspect of the importance level but has low score in term of performance. This section presents the position of customer's dissatisfaction. Quadrant II, the "Keep up the Good Work" represents high score from the aspect of importance level and performance. Aspects in this section are ideal since they indicate the advantage an organization has in the fields considered importance by customers. Quadrant III, the "Low Priority", means that both score of importance level and performance are low. Aspects fall in this section can be ignored from the focus of attention of the management in the future. Quadrant IV, the "Possibly Overkill", means that the score of importance level is low but the score of performance is high.

\begin{tabular}{|c|c|}
\hline $\begin{array}{l}\text { Quadrant I } \\
\text { Concentrate Here } \\
\text { Attributes in this quadrant are } \\
\text { considered to be crucial by } \\
\text { customers but the performance is } \\
\text { less satisfying so that the company } \\
\text { has to improve the quality of its } \\
\text { service. }\end{array}$ & $\begin{array}{l}\text { Quadrant II } \\
\qquad \text { Keep Up The Good Work } \\
\text { Attributes in this quadrant is } \\
\text { considered to be crucial by customers } \\
\text { and the performance is satisfying, } \\
\text { therefore, the company must } \\
\text { maintain the quality of its service. }\end{array}$ \\
\hline $\begin{array}{l}\text { Quadrant III } \\
\text { Low Priority }\end{array}$ & $\begin{array}{c}\text { Quadrant IV } \\
\text { Possible Overkill }\end{array}$ \\
\hline $\begin{array}{l}\text { Attributes in this quadrant is } \\
\text { considered to be less important by } \\
\text { customers and the performance is } \\
\text { less satisfying. }\end{array}$ & $\begin{array}{l}\text { Attributes in this quadrant is } \\
\text { considered to be less important by } \\
\text { customers, but the performance is } \\
\text { satisfying. }\end{array}$ \\
\hline
\end{tabular}

Figure 4. Strategy of Importance Performance Analysis (IPA)
These results show that the organization give too much attention to aspects that have low effects towards customers' satisfaction so that the resource that used to be allocated to this section can be re-distributed to other aspects that have high score of performance level but still has low performance. For further understanding, check the figure 4.

Martilla and James (1977) explain the Position of Quadrant Placement in the Importance Performance Analysis (IPA) by providing a placement of analyzed data into four sections: Quadrant 1 (Concentrate here), Quadrant 2 (Keep up the good work), Quadrant 3 (Low priority), and Quadrant 4 (Possible overkill). More detailed information can be found in figure 5 .

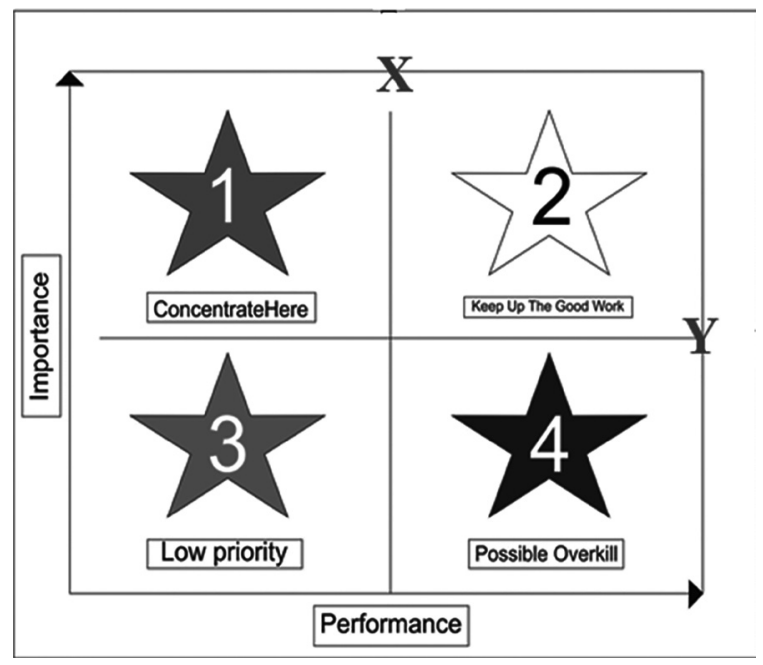

Figure 5. Position of IPA Quadrant Placement

\section{Results \& Discussion \\ Distribution of Respondents' Responses Frequency}

Results in the form of statistical data were obtained from the stakeholders (government, management/enterprise, and local tourism community) based on questions of 8 indicators in performing effective synergy. The details are presented in the Table 3.

Table 3

Synergy among Stakeholders

\begin{tabular}{lccc}
\hline \multicolumn{1}{c}{ Responses } & Frequency & $\begin{array}{c}\text { Percentage } \\
(\%)\end{array}$ & Mean \\
\hline Strongly Disagree & 0 & 0.0 & \\
Disagree & 0 & 0.0 & \\
Neutral & 5 & 33.3 & 4.0 \\
Agree & 5 & 33.3 & \\
Strongly Agree & 5 & 33.3 & \\
\hline
\end{tabular}


Referring to Table 3, based on the results of statistical analysis on the Synergy among Stakeholders, the results of responses given by respondents showed that those who answered Strongly Disagree were $0 \%$, those who answered Disagree were $0 \%$, those who gave Neutral answers were $33.3 \%$, those who answered Agree were $33.3 \%$, and those who answered Strongly Agree were $33.3 \%$. The average value obtained from this item was 4.0 points, which means many tend to agree with the value of interest and performance in Synergy among Stakeholders.

Table 4

Environmental Changes (X1)

\begin{tabular}{lccc}
\hline \multicolumn{1}{c}{ Responses } & Frequency & $\begin{array}{c}\text { Percentage } \\
(\%)\end{array}$ & Mean \\
\hline Strongly Disagree & 0 & 0.0 & \\
Disagree & 0 & 0.0 & \\
Neutral & 0 & 0,0 & 4.0 \\
Agree & 5 & 100,0 & \\
Strongly Agree & 0 & 0,0 & \\
\hline
\end{tabular}

Source: Primary data, 2019

Referring to Table 4, based on the results of statistical analysis on Environmental Changes, the results of responses given by respondents showed that those who answered Strongly Disagree were 0\%, those who answered Disagree were $0 \%$, those who gave Neutral answers were $0 \%$, those who answered Agree were $100 \%$, and those who answered Strongly Agree were 0\%. The average value obtained from this item was 4.0 points, which means many tend to agree with the value of interest and performance in Environmental Changes.

TTable 5

Simultaneous Policy (X2)

\begin{tabular}{lccc}
\hline \multicolumn{1}{c}{ Responses } & Frequency & $\begin{array}{c}\text { Percentage } \\
(\%)\end{array}$ & Mean \\
\hline Strongly Disagree & 0 & 0.0 & \\
Disagree & 0 & 0.0 & \\
Neutral & 10 & 66.7 & 3.3 \\
Agree & 5 & 33.3 & \\
Strongly Agree & 0 & 0,0 & \\
\hline
\end{tabular}

Source: Primary data, 2019

Referring to Table 5, based on the results of statistical analysis on Simultaneous Policy, the results of responses given by respondents showed that those who answered Strongly Disagree were $0 \%$, those who answered Disagree were $0 \%$, those who gave Neutral answers were $66.7 \%$, those who answered Agree were 33.3\%, and those who answered Strongly Agree were 0\%. The average value obtained from this item was 3.3 points, which means many tend to agree with the value of interest and performance in Simultaneous Policy.
Table 6 Continuous Coordination (X3)

\begin{tabular}{lccc}
\hline \multicolumn{1}{c}{ Responses } & Frequency & $\begin{array}{c}\text { Percentage } \\
(\%)\end{array}$ & Mean \\
\hline Strongly Disagree & 0 & 0,0 & \\
Disagree & 5 & 33,3 & \\
Neutral & 0 & 0,0 & 4,0 \\
Agree & 5 & 33,3 & \\
Strongly Agree & 0 & 0,0 & \\
\hline \multicolumn{1}{c}{ Source: Primary data, 2019 } & &
\end{tabular}

Referring to Table 6, based on the results of statistical analysis on Continuous Coordination, the results of responses given by respondents showed that those who answered Strongly Disagree were 0\%, those who answered Disagree were $33.3 \%$, those who gave Neutral answers were $0 \%$, those who answered Agree were 33.3\%, and those who answered Strongly Agree were $0 \%$. The average value obtained from this item was 4.0 points, which means many tend to agree with the value of interest and performance in Continuous Coordination.

Table 7

Simultaneous Responsibility (X4)

\begin{tabular}{lccc}
\hline \multicolumn{1}{c}{ Responses } & Frequency & $\begin{array}{c}\text { Percentage } \\
(\%)\end{array}$ & Mean \\
\hline Strongly Disagree & 0 & 0,0 & \\
Disagree & 10 & 66,7 & \\
Neutral & 0 & 0,0 & 3,0 \\
Agree & 0 & 0,0 & \\
Strongly Agree & 5 & 33,3 & \\
\hline \multicolumn{2}{c}{ Source: Primary data, 2019 } & &
\end{tabular}

Referring to Table 7, based on the results of statistical analysis on Simultaneous Responsibility, the results of responses given by respondents showed that those who answered Strongly Disagree were 0\%, those who answered Disagree were $66.7 \%$, those who gave Neutral answers were $0 \%$, those who answered Agree were $0 \%$, and those who answered Strongly Agree were $33.3 \%$. The average value obtained from this item was 3.0 points, which means that many tend to agree with the value of interest and performance in Simultaneous Responsibility.

Table 8

Obvious Purpose (X5)

\begin{tabular}{lccc}
\hline \multicolumn{1}{c}{ Responses } & Frequency & $\begin{array}{c}\text { Percentage } \\
(\%)\end{array}$ & Mean \\
\hline Strongly Disagree & 0 & 0,0 & \\
Disagree & 5 & 33,3 & \\
Neutral & 0 & 0,0 & 4,0 \\
Agree & 5 & 33,3 & \\
Strongly Agree & 5 & 33,3 & \\
\hline \multicolumn{1}{c}{ Source Primary data, 2019} & & &
\end{tabular}

Source: Primary data, 2019

Referring to Table 8 , based on the results of statistical analysis on Obvious Purpose, the results of responses given by 
respondents showed that those who answered Strongly Disagree were $0 \%$, those who answered Disagree were $33.3 \%$, those who gave Neutral answers were $0 \%$, those who answered Agree were 33.3\%, and those who answered Strongly Agree were $33.3 \%$. The average value obtained from this item was 4.0 points, which means many tend to agree with the value of interest and performance in Obvious Purpose.

Referring to Table 9, based on the results of statistical analysis on Direct Relationship, the results of responses given by respondents showed that those who answered Strongly Disagree were 0\%, those who answered Disagree were $0 \%$, those who gave Neutral answers were $66.7 \%$, those who answered Agree were 33.3\%, and those who answered Strongly Agree were 0\%. The average value obtained from this item was 3.3 points, which means that many tend to agree with the value of interest and performance in Direct Relationship.

Table 9

Direct Relationship (X6)

\begin{tabular}{lccc}
\hline \multicolumn{1}{c}{ Responses } & Frequency & $\begin{array}{c}\text { Percentage } \\
(\%)\end{array}$ & Mean \\
\hline Strongly Disagree & 0 & 0,0 & \\
Disagree & 0 & 0,0 & \\
Neutral & 10 & 66,7 & 3,3 \\
Agree & 5 & 33,3 & \\
Strongly Agree & 0 & 0,0 & \\
\hline
\end{tabular}

Source: Primary data, 2019

Referring to Table 10, based on the results of statistical analysis on Effective Communication, the results of responses given by respondents showed that those who answered Strongly Disagree were $0 \%$, those who answered Disagree were $0 \%$, those who gave Neutral answers were $33.3 \%$, those who answered Agree were 33.3\%, and those who answered Strongly Agree were $33.3 \%$. The average value obtained from this item was 4.0 points, which means that many tend to agree with the value of interest and performance in Effective Communication.

Table 10

Effective Communication (X7)

\begin{tabular}{lccc}
\hline \multicolumn{1}{c}{ Responses } & Frequency & $\begin{array}{c}\text { Percentage } \\
(\%)\end{array}$ & Mean \\
\hline Strongly Disagree & 0 & 0,0 & \\
Disagree & 0 & 0,0 & \\
Neutral & 5 & 33,3 & 4,0 \\
Agree & 5 & 33,3 & \\
Strongly Agree & 5 & 33,3 & \\
\hline
\end{tabular}

Referring to Table 11, based on the results of statistical analysis on Simultaneous Supervision, the results of responses given by respondents showed that those who answered Strongly Disagree were $0 \%$, those who answered Disagree were $33.3 \%$, those who gave Neutral answers were $0 \%$, those who answered Agree were 33.3\%, and those who answered Strongly Agree were $33.3 \%$. The average value obtained from this item was 4.0 points, which means many tend to agree with the value of interest and performance in Simultaneous Supervision.

Table 11 Simultaneous Supervision (X8)

\begin{tabular}{lccc}
\hline \multicolumn{1}{c}{ Responses } & Frequency & $\begin{array}{c}\text { Percentage } \\
(\%)\end{array}$ & Mean \\
\hline Strongly Disagree & 0 & 0,0 & \\
Disagree & 5 & 33,3 & \\
Neutral & 0 & 0,0 & 4,0 \\
Agree & 5 & 33,3 & \\
Strongly Agree & 5 & 33,3 & \\
\hline
\end{tabular}

Source: Primary data, 2019

\section{Analysis of Importance Performance Analysis (IPA)}

The result on the analysis of Importance Performance Analysis (IPA) concerning the attributes of synergy discover that attribute $X 1$ falls into quadrant $I$, that is Environmental Changes; attributes $X 3, X 4, X 7 \& X 8$ fall into quadrant II, which are Continuous Coordination, Simultaneous Responsibility, Effective Communication, and Simultaneous Supervision; attribute $\mathrm{X} 2 \& \times 6$ fall into quadrant III, which are Simultaneous Policy and Direct Relationship; last is attribute X5 that falls into quadrant IV, which is Obvious Purpose. Thus, attention should be paid to the perception that tourism stakeholders in the management of migrant tourism villages is considered important and have a significant performance in terms of continuous coordination in facing environmental changes. The attributes in the analysis of Importance Performance Analysis are presented in figure 6.

Placement based on the results of IPA analysis (Synergy attribute) decides that X1 falls into quadrant I; attributes $X 3, X 4, X 7$ \& $X 8$ fall into quadrant II; attributes $X 2 \& X 6$ fall into quadrant III; and attribute X5 falls into quadrant IV; whereas the demonstration of the placement is presented in Figure 7.

The results of IPA analysis are as follows: the first one is quadrant I, where the concentrate is occupied only by attribute $\mathrm{X} 1$, which means that the attributes in this 
quadrant are considered very important by stakeholders but the performance is not satisfactory so that the tourism business must improve the quality of its services. The results state that quadrant I is obtained by attribute $\mathrm{X} 1$, namely the environmental changes, but not yet maximally performed. It means that $\mathrm{X} 1$ is the perception of tourism stakeholders in managing migrant tourism villages, who realize the importance of dealing with environmental changes both internal and external, but their performance is still not yet optimal. Again, it means that stakeholder performance in dealing with environmental changes is still not yet optimal.

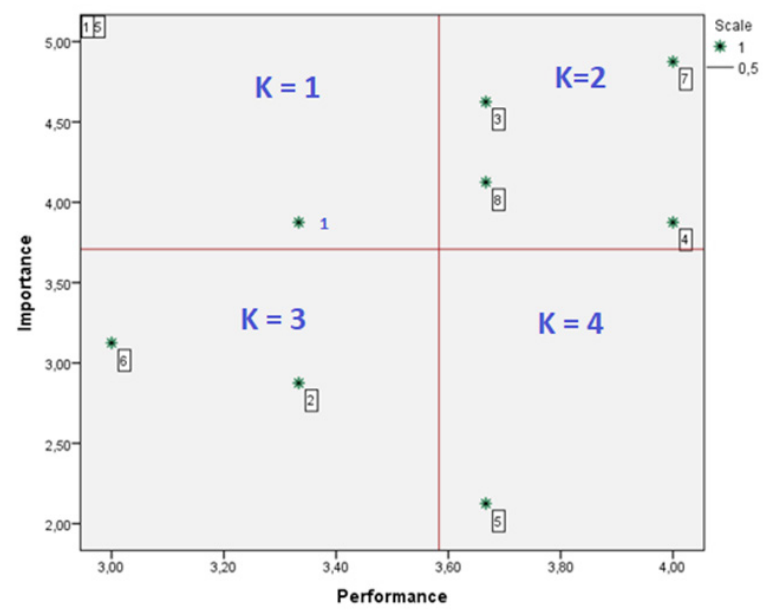

Figure 6. Analysis on the Attributes of Synergy in 4 Quadrants

\begin{tabular}{|c|c|}
\hline $\begin{array}{l}\text { Quadrant I } \\
\text { (Concentrate Here) } \\
\text { Number of Attributer } \\
\text { XI }\end{array}$ & $\begin{array}{l}\text { Quadrant II } \\
\text { (Keep Up The Good Work) } \\
\text { Number, of Attribute: } \\
X 3, X 4, X 7, X 8\end{array}$ \\
\hline $\begin{array}{l}\text { Quadrant III } \\
\text { (Low Priority) } \\
\text { Number, of Attributes } \\
\text { X2,16 }\end{array}$ & $\begin{array}{l}\text { Quadrant IV } \\
\text { (Possibly Overkill) } \\
\text { Number, of Attribute: } \\
\text { X5 }\end{array}$ \\
\hline
\end{tabular}

Figure 7. IPA's Result of Decision

This statement supports the results of research concerning the condition of policy collaboration (Mukhlis et al, 2019). Therefore, the next expected action is a comprehensive improvement by stakeholders in dealing with environmental changes, both internal and external.
The next result is concerning quadrant II or quadrant of Keep up the Good Work. The attributes in this quadrant are considered very important by stakeholders and their performance is very satisfying so that tourism businesses must maintain the service quality. The results of research in quadrant II are occupied by 4 attributes, namely X3, X4, $X 7$, and $X 8$. These attributes in quadrant II reveal that the perception of tourism stakeholders in the management of migrant tourism villages is considered very important and already has satisfactory performance in making institutional arrangements. This statement in quadrant II supports the result of a research on Public Relations Marketing Strategy in Preparing Halal Tourism in Priangan Region. The result of this study explains that the driving strategy undertaken by the government is the dissemination of tourism policies to tourism stakeholders. The strategy is carried out by framing the news on social media about the potential goals in the development of halal tourism by the tourism community (Perbawasari, 2019) and (Nafi, 2018). There is a correlation between media type, media content, media exposure and social context in watching Youtube with the fulfillment of information needs (Dadi Ahmadi, Sabarina, \& Harahap, 2020)

The attribute of $X 3$ relates to continuous and sustainable coordination. $\mathrm{X} 4$ represents shared responsibilities between each stakeholders or institutions that have interests in managing tourism. $X 7$ is the implementation of effective communication among tourism stakeholders who manage migrant tourism villages in Malang District. X8 is effective joint supervision between stakeholders in the implementation of tourism activities. All the attributes of X3, X4, X7, \& X8 are considered crucial by tourists and also describe the satisfying performance of the stakeholders. Therefore, these forms of attributes should be maintained through continuous coordination in performing all matters for the interests and welfare of migrant village communities. This statement supports the findings in research on the potential of ecotourism and community welfare in Lombok (Natalia, 2017).

Still in quadrant II, the attributes, as mentioned earlier, are $\mathrm{X} 3, \mathrm{X} 4, \mathrm{X} 7$, and $\mathrm{X} 8$ which can be stated as follows: the perception of tourism stakeholders in the management of migrant tourism villages is considered very important and already has a performance in conducting institutional arrangements in carrying out shared responsibilities among 
stakeholders.

Perception on attribute $X 7$, namely effective communication between tourism stakeholders in the management of migrant tourism villages, is considered to be very important and has already demonstrated effective communication performance. Next is $\mathrm{X} 8$, the perception of tourism stakeholders in the management of migrant tourism villages towards sustainable supervision. It is considered very important and has shown performance in conducting joint supervision effectively on the course of tourism activities in migrant villages in District of Malang.

The next result in this study is the position of quadrant III, the Low Priority quadrant, which is less prioritized. This means that the attributes in this quadrant are considered not important by stakeholders or tourists, and their performance is insufficient. The third quadrant is occupied by attributes $\times 2$ and $X 6$ that represent joint planning and policy activities in direct coordination. Here, the perception of tourism stakeholders in the management of migrant tourism villages is declared to have performance, but this attribute is not so important in the formal direct coordination process.

The next result in this study is quadrant IV, the Possible Overkill quadrant. This attribute explains that quadrants in this position are considered not important by stakeholders, but their performance is satisfactory. It's different from the attributes in quadrant III where the position of the attribute is considered not important by stakeholders and its performance is also unsatisfactory. The attribute occupying the position in quadrant IV is $\times 5$ (doing the goal activities together). This means that migrant village tourism managers, or we call them stakeholders, always apply visionary thinking. This is considered not so important, but its performance is satisfactory, so that the corrective action taken is to see and evaluate the value of the level of importance and fundamentals in general to formulate common goals.

Evaluation of tourism stakeholder's perception on the attributes of important values and institutional performance values in tourism through IPA was conducted for the purpose of improving quid pro quo values for the welfare of migrant community. Hence, there are several suggestion and recommendation reagarding the above evaluation. Firstly, tourism stakeholders are suggested to perform extra works through cooperation in countering environmental changes, both internal and external, so that it can create sustainable welfare. Secondly, it is recommended for tourism stakeholders to maintain a continuous coordinative performance in making institutional arrangements, joint responsibility, effective communication, and joint-supervision. Thirdly, a suggestion for tourism stakeholders to improve the performance through synergy based on the values of enjoyed benefits.

Table 2

Analysis of IPA Suitability

\begin{tabular}{|c|c|c|}
\hline $\begin{array}{l}\text { Number of } \\
\text { Attributes }\end{array}$ & Attributes & $\begin{array}{l}\text { Correctional } \\
\text { Measures }\end{array}$ \\
\hline $\mathbf{K} \mathbf{I}=\mathbf{X I}$ & $\begin{array}{l}\text { Tourism stakeholders' perception } \\
\text { in managing migrant tourism } \\
\text { village states that it is very } \\
\text { important } \\
\text { environmental changes, but the } \\
\text { performance in countering the } \\
\text { environmental changes hasn't } \\
\text { been optimum. }\end{array}$ & $\begin{array}{l}\text { The importance of } \\
\text { extra improvement } \\
\text { through cooperation } \\
\text { in countering } \\
\text { environmental both } \\
\text { changes, } \\
\text { internal and external. }\end{array}$ \\
\hline $\begin{array}{l}\text { K II } \\
\times 4, X\end{array}$ & 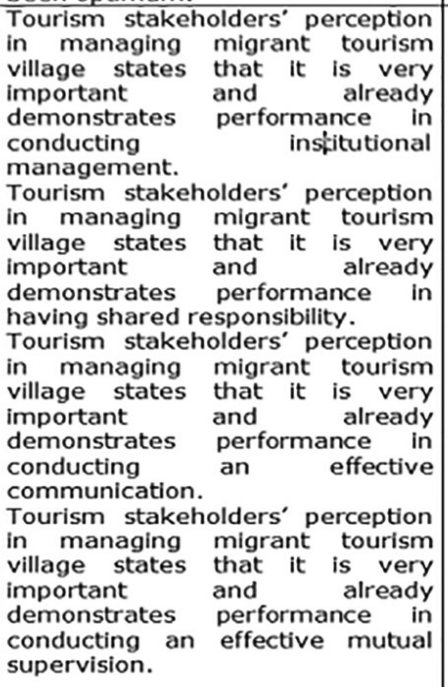 & $\begin{array}{l}\text { The form of this } \\
\text { attributes should be } \\
\text { maintained } \\
\text { continuous by } \\
\text { coordination } \\
\text { performing in } \\
\text { institutional } \\
\text { management. }\end{array}$ \\
\hline \multirow[t]{2}{*}{$\underset{8 \times 6}{K \text { III }}=\times 2$} & $\begin{array}{l}\text { Tourism stakeholders' perception } \\
\text { in managing migrant tourism }\end{array}$ & $\begin{array}{l}\text { Improving } \\
\text { synergistic }\end{array}$ \\
\hline & $\begin{array}{l}\text { village states that it has not } \\
\text { indicated any performances and } \\
\text { this attribute is considered to be } \\
\text { not so important in the making of } \\
\text { specific regulation } \\
\text { Tourism stakeholders' perception } \\
\text { in managing migrant tourism } \\
\text { village states that it has not } \\
\text { indicated any performances and } \\
\text { this attribute is considered to be } \\
\text { not so important in conducting } \\
\text { formal coordination. }\end{array}$ & $\begin{array}{l}\text { perfomance based } \\
\text { on the value of the } \\
\text { benefit. }\end{array}$ \\
\hline K IV = X5 & $\begin{array}{l}\text { Tourism stakeholders' perception } \\
\text { in managing migrant tourism } \\
\text { village states that it indicates } \\
\text { performances but this attribute is } \\
\text { considered to be not so important } \\
\text { in visionary thinking. }\end{array}$ & $\begin{array}{l}\text { Assess and evaluate } \\
\text { the value of interests } \\
\text { in general and reform } \\
\text { the mutual } \\
\text { objectives. }\end{array}$ \\
\hline
\end{tabular}


Fourthly, tourism stakeholders should reevaluate the values of interests that affect the public.

\section{Analysis of Suitability}

The result of IPA suitability analysis indicates stakeholder's perceptions in assessing each of the management attributes of migrant tourism villages and comparing the importance of an attribute with the level of performance of an attribute when managing migrant tourism villages. This analysis also includes the recommended corrective actions. The more detailed data can be seen in Table 12.

\section{Conclusions}

The evaluation of tourism stakeholder's perceptions on the attributes of important values and the value of performance of tourism institutions in the context of increasing the value of quid pro quo for the welfare of migrant communities has several attributes, namely Environmental Changes that falls into Quadrant 1; attributes of Continuous Coordination, Simultaneous Responsibility, Effective Communication, and Simultaneous Supervision that fall into Quadrant 2; attributes of Simultaneous Policy, and Direct Relationship that fall into Quadrant 3; and the last is Obvious Purpose that falls into Quadrant 4.

The improvements that must be made to increase the value of quid pro quo for the welfare of migrant communities are as follows: first, tourism stakeholders are encouraged to do extra work through cooperation in dealing with environmental changes, both internal and external, so as to create sustainable prosperity. Second, tourism stakeholders are expected to be able to maintain a continuous coordination performance in carrying out institutional arrangements, joint responsibility, effective communication, and joint supervision. Third, tourism stakeholders are advised to improve synergistic performance based on the perceived benefits. The last one, tourism stakeholders are encouraged to re-evaluate the value of interests that affect the public.

\section{References}

Ahmadi, Dadi, Sabarina, C., \& Harahap, E. H. (2020). Implementation Information Technology Through Channel Youtube "Lampu Islam." 409(SoRes 2019), 630-631. https://doi.org/10.2991/ assehr.k.200225.137

Aitken C. and C. M. Hall, (2010). "Migrant and foreign skills and their relevance to the tourism industry," Tour. Geogr., vol. 2 , no. 1, pp. 66-86.

Afrindo, (2014). "Strategi Advokasi Berjejaring Terhadap Tenaga Kerja Indonesia Oleh Serikat Buruh Migran Indonesia (Sbmi) Malang," J. Ilmu Pemerintah. Univ. Brawijaya Malang, vol. 7, no. 13, pp. $1-21,2014$

Ansoff, H.I., (1965.)Corporate Strategy: An Analytic Approach to Business Policy for Growth and Expansion, McGraw-Hill, New York, NY, 1965.

Badan Pusat Statistik (BPS). (2017). Kabupaten Malang Dalam Angka 2017, vol. 17. 2017.

Beik, I. S. (2018). Inovasi Ekonomi Sosial Syariah. Harian Republika edisi 22 Maret 2018

Brouder, P., \&Rikard H. E. (2013). Tourism evolution: On the synergies of tourism studies and evolutionary economic geography. Annals of Tourism Research, 43, 370-389. https://doi.org/10.1016/j. annals.2013.07.001

Dabestani, R., Shahin, A., Saljoughian, M., \& Shirouyehzad, H. (2016). Importanceperformance analysis of service quality dimensions for the customer groups segmented by DEA: The case of four star hotels. International Journal of Quality and Reliability Management, 33(2), 160-177. https://doi.org/10.1108/ IJQRM-02-2014-0022

Deepa, R., \& Baral, R. (2019). Importanceperformance analysis as a tool to guide employer branding strategies in the ITBPM industry. Journal of Organizational Effectiveness, 6(1), 77-95. https://doi. org/10.1108/JOEPP-04-2018-0024

Dibra, M. (2015). Rogers Theory on Diffusion of Innovation-The Most Appropriate Theoretical Model in the Study of Factors Influencing the Integration of Sustainability in Tourism Businesses. Procedia Social and Behavioral Sciences, 195, 1453-1462. https://doi.org/10.1016/j. sbspro.2015.06.443

Giambi, C., Del Manso, M., Dalla Zuanna, T., Riccardo, F., Bella, A., Caporali, M. G., Baka, A., Caks-Jager, N., Melillo, T., Mexia, R., Petrović, G., \& Declich, S. (2019). National immunization strategies targeting migrants in six European countries. Vaccine, 37(32), 4610-4617. https://doi. org/10.1016/j.vaccine.2018.01.060

Nafi, B. Supriadi, and N. Roedjinandari, 
(2018), "Internal Marketing Impact On External Service Quality in Semeru

Itami, H. and Roehl, T.H., (1987), Mobilizing Invisible Assets, Harvard University Press, Cambridge, MA.

Joppe, M. (2012) "Migrant workers: Challenges and opportunities in addressing tourism labour shortages," Tour. Manag., vol. 33, no. 3, pp. 662-671,.

Janta, H., L. Brown, P. Lugosi, and A. Ladkin, (2011), "Migrant relationships and tourism employment," Ann. Tour. Res., vol. 38, no. 4, pp. 1322-1343,

Kemenakertrans. (2017). Pedoman Program Desmigratif 2017.

Kemendag, (2012), 14 Sektor Industri Kreatif, Departemen Perdagangan RI, Jakarta

Latifah, S. W. (2014), "Strategi Advokasi Berjejaring Terhadap Tenaga Kerja Indonesia Oleh Serikat Buruh Migran Indonesia (Sbmi) Malang," J. Ilmu Pemerintah., vol. 6, no. 1, pp. 1-20, 2014.

Martilla, J.A. and James, J.C. (1977), "Importance-performance analysis", Journal of Marketing, Vol. 41.

Mukhlis, M., Rahmatunnisa, M., \& Yuningsih, N. Y. (2019). Starting Condition Problems in Collaboration of Lampung Province Central Government Displacement Policy. MIMBAR : Jurnal Sosial Dan Pembangunan, 35(1), 1-10. https://doi.org/10.29313/ mimbar.v35i1.3667

Moekijat. (1994). Koordinasi (Suatu Tinjauan Teoritis). Bandung: Mandar Maju

Natalia, \& Supriadi, B. (2017). Potensi ekowisata dan kesejahteraan masyarakat. Pesona Pariwisata, 2(02), 1-12.

Perbawasari, S., Sjuchro, D. W., Setianti, Y., Nugraha, A. R., \& Hafiar, H. (2019). Government Marketing Public Relations Strategy in Preparing Halal Tourism in Priangan Region. MIMBAR : Jurnal Sosial Dan Pembangunan, 35(1), 89103. https://doi.org/10.29313/mimbar. v35i1.4134

Pitana, Gayatri, Haryanti, Nugroho. (2018), Sinergi Stakeholder Dalam Mewujudkan Aktivitas Pariwisata Di Desa Wisata Baha, Kecamatan Mengwi, Kabupaten Badung. Jurnal Destinasi Pariwisata. Vol. 5 No 2.

Prayitno, G., A. A.Nugraha, N. Sari, and P. U. Y. Balqis,(2013), "The Impact of International Migrant Workers on Rural Labour Availability (Case Study Ganjaran Village, Malang Regency)," Procedia Environ. Sci., vol. 17, pp. 992-998, 2013

Roger, E. M., (1995), Diffusion of Innovations, Fourth edition, New York: Free Press.

Sedarmayanti, Wahyudi, Azwari, Alfajr, Septiani. (2018). Sinergisitas Organisasi Publik Dengan Mengimpletasikan Sukuk Wakaf Melalui Pembentukan Halal Center Industry. Simposium Nasional KeuanganNegara.

Santeramo, F. G., Seccia, A., \& Nardone, G. (2017). The synergies of the Italian wine and tourism sectors. Wine Economics and Policy, 6(1), 71-74. https://doi. org/10.1016/j.wep.2016.11.004

Silalahi, Wahyudi, Azwari, Alfajr, Septiani. (2018). Sinergisitas Organisasi Publik Dengan Mengimpletasikan Sukuk Wakaf Melalui PembentukanHalal Center Industry. Simposium Nasional KeuanganNegara.

Wahyudi, D., Azwari, P. C., Alfajr, A., \& Septiani, S. D. (2018), Sinergitas Organisasi Publik Dengan Mengimplementasikan Sukuk Wakaf Melalui Pembentukan Halal Center Industry. Simposium Nasional Keuangan Negara Sinergitas, 718-743.

Walton, J. (1999). Strategic Human Resource Development. Pearson Education Limited. Edinburg.

Weiss, R.A., (1995), The Cracks in the Foundation of Stakeholder Theory. Available at: http://www.mngt.waikato. ac.nz/ejrot/Vol1_1/Weiss.pdf. 